\title{
NEUROMUSCULAR INJURY METHOD IN DIFFERENT STRENGTH SPORTS DAMAGE
}

\section{MÉTODO DE LESÃO NEUROMUSCULAR EM DANOS VARIADOS CAUSADOS POR ESPORTES DEFORÇA} MÉTODO DE LESIÓN NEUROMUSCULAREM DAÑOS VARIADOS CAUSADOS POR DEPORTES DE FUERZA

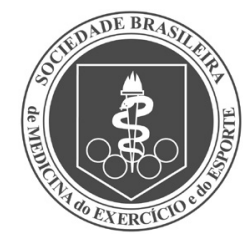

Original Article ARTIGO ORIGINAL Artículo Original
Yongfen Yang 1 (D)

(Physical Education Professional)

Zhenting Chen² (D)

(Physical Education Professional)

1. College of Physical Education, Kunming University, Kunming, Yunnan, China.

2. College of Information

Engineering, Kunming University Kunming, Yunnan, China.

\section{Correspondence}

Zhenting Chen

Kunming, Yunnan, China, 650214 chenzhenting39@163.com

\begin{abstract}
Introduction: Sports muscle injury is a common phenomenon in sports, and most of it is caused by intense exercise done for a long time. Objective: The effect of high intensity mode (HI) speed endurance training on the muscle injury of athletes. Methods: 14 sprinters were recruited; the muscle injury indexes of the subjects were tested $15 \mathrm{~min}$ before and $24 \mathrm{~h}, 48 \mathrm{~h}$ and $72 \mathrm{~h}$ after speed endurance training in HV mode and $\mathrm{HI}$ mode (high volume mode and high intensity mode, respectively). Results: The results of this study showed that both high amount and $\mathrm{HI}$ mode speed endurance training caused a certain degree of injury to the subjects' muscles, but the injury caused by $\mathrm{HI}$ mode speed endurance training to the muscles was more serious than that caused by high amount $(P<0.05)$. Conclusions: $\mathrm{HI}$ mode speed endurance training causes a certain degree of injury to the subjects' muscle, but it causes more serious injury than high volume mode speed endurance training. Level of evidence Il; Therapeutic studies - investigation of treatment results.
\end{abstract}

Keywords: Abdominal muscles; High-intensity interval training; Exercise.

\section{RESUMO}

Introdução: As lesões musculares são fenômenos comuns no esporte e a maioria são causadas por exercícios intensos praticados por um longo período. Objetivo: O efeito do treinamento de resistência de velocidade de alta intensidade (Al) nas lesões musculares de atletas. Métodos: 14 corredores foram recrutados; os índices de lesão muscular dos indivíduos foram testados 15 minutos antes e 24h, 48h e $72 \mathrm{~h}$ após o treino de resistência de velocidade em AV e Al (modos alto volume e alta intensidade, respectivamente). Resultados: Os resultados deste estudo mostram que tanto os treinamentos de resistência de velocidade nos modos alto volume e Al causaram certo grau de lesão aos músculos dos indivíduos, mas a lesão ao músculo por treino de resistência de velocidade no modo Al foi mais severa do que aquela no modo alto volume $(P<0.05)$. Conclusões: $O$ treinamento de resistência de velocidade no modo Al causa certo grau de lesão aos músculos dos indivíduos, mas causa danos mais sérios do que o treino de resistência de velocidade no modo alto volume. Nível de evidência ll; estudos terapêuticos - investigação de resultados de tratamento.

Descritores: Músculos abdominais; Treinamento intervalado de alta intensidade; Exercício físico.

\section{RESUMEN}

Introducción: Las lesiones musculares son fenómenos comunes en el deporte y la mayoría es causada por ejercicios intensos practicados por un largo periodo. Objetivo: El efecto del entrenamiento de resistencia de velocidad de alta intensidad (Al) en las lesiones musculares de atletas. Métodos: Se reclutaron 14 corredores; se testaron los índices de lesión muscular de los individuos 15 minutos antes y 24h, 48h y $72 \mathrm{~h}$ después del entrenamiento de resistencia de velocidad en AV y Al (modos alto volumen y alta intensidad, respectivamente). Resultados: Los resultados de este estudio muestran que tanto los entrenamientos de resistencia de velocidad en los modos alto volumen y Al causaron cierto grado de lesión a los músculos de los individuos, pero la lesión al músculo por entrenamiento de resistencia de velocidad en el modo Al fue más severa que aquella en el modo alto volumen $(P<0.05)$ Conclusiones: El entrenamiento de resistencia de velocidad en el modo Al causa cierto grado de lesión a los músculos de los individuos, pero causa daños más serios que el entrenamiento de resistencia de velocidad en el modo alto volumen. Nivel de evidencia Il; Estudios terapéuticos - investigación de resultados de tratamiento.

Descriptores: Músculos abdominales; Entrenamiento de intervalos de alta intensidad; Ejercicio físico.

\section{INTRODUCTION}

Exercise-induced Muscle Damage (EIMD) refers to the Damage caused by repeated high-intensity Exercise, non-routine Exercise, resistance Exercise, long-term Exercise and centrifugal Exercise to the skeleton and membrane of Muscle cells, which is an unavoidable part of sports training. Is exercise and professional people in the general population in a very common phenomenon in sports training, light person affect daily life, the person that weigh restricts the development of motor skills, in recent years, more and more literature has reported that the sports physiological mechanism, the adaptation mechanism of the muscle damage and intervention measures, 
its purpose is to reduce the exercise-induced muscle damage to the negative impact of sports training practice. ${ }^{2}$ In some experiments, the knee and elbow extensor muscles were induced by isokinetic force measurement or specially designed instruments, while in the other experiment, the knee and elbow extensor muscles were induced by downhill deceleration and hyperlength exercise. Although the above studies have provided profound insights into many complex issues of exercise-induced muscle injury. ${ }^{3}$ But in sports training practice, there are many kinds of special training programs, and the causes and results of injury are also complicated. Therefore, the injury mechanism of all forms of specialized training programs has not been studied and reported in previous studies. ${ }^{4}$

\section{METHOD}

\section{Experimental Methods}

The subjects in this study were 14 male sprinters (age 18.57 \pm 2.56 years old, height $181.00 \pm 5.16 \mathrm{~cm}$, weight $68.00 \pm 6.45 \mathrm{~kg}$, training years $6.35 \pm 2.92$ years, best performance $22.19 \pm 1.06 \mathrm{~s}$ in $200 \mathrm{~m}$ ). The basic information of athletes is shown in Table 1.5

In order to ensure the accuracy of the experimental results, the training intensity, speed rhythm, interval time, physical activity, nutritional supplement and other aspects of the two speed endurance training modes of HV and high volume were controlled in the experiment. Specific methods were as follows:

(1) Control of training intensity. ${ }^{6}$ The training intensity of the subjects was recorded using a photoelectric timing system. All subjects were required to use a standing start for the test, and the timing was started or stopped when the subjects' torso simultaneously cut off the infrared beam.

(2) Speed and rhythm control. According to the preset training intensity of the test, the speed of the e-bike under different training intensities was recorded, and the speed was corrected several times. Through many tests, it has been proved that the error of the guide riding $200 \mathrm{~m}$ on the outdoor track can be controlled within $20 \sim 30 \mathrm{~cm}$. According to the speed on the speed display of the electric vehicle, cycling guidance is carried out $2 \mathrm{~m}$ ahead of the subject's outer path to provide reference for the speed control of the subject?

(3) Control of intermission time. The electronic stopwatch is used to control the training interval of the subjects, that is, when the subjects'torso passes the finish line, the electronic stopwatch is started immediately, and the athletes are required to rest in the designated position in place; When the interval time is 30 seconds, the timekeeper will remind the subjects to get ready for the test at the starting point, and count down the command of " $5,4,3,2,1$, run" during the last 5 seconds. When the subjects hear the command of "run", they will start running immediately. Muscle Stiffness (MS. Using digital MyotonPRO muscle function evaluation system (MyotonPRO, E7, ida-virumaa county, Esthonia) of the subjects non-dominant hardness test of the biceps femoris muscle in his leg. Before the test, the subjects were asked to lie prone on the massage table wearing only running shorts, and a special marker was used to mark the middle of the subjects' biceps muscles to ensure that the test spot was in the same position each time. At the start of the experiment, the experimenter measured the stiffness of the biceps femoris muscle of the subjects' non-dominant leg against the markers. Each subject was tested for 3 times, and the maximum value of the 3 tests was recorded and used for data analysis. ${ }^{8}$

Table 1. Basic information table of athletes.

\begin{tabular}{c|c|c|c|c|c}
\hline $\begin{array}{c}\text { number of } \\
\text { people }\end{array}$ & $\begin{array}{c}\text { number } \\
\text { of people }\end{array}$ & Age & $\begin{array}{c}\text { Body } \\
\text { Weight }(\mathbf{k g})\end{array}$ & Height (cm) & $\begin{array}{c}\text { Training } \\
\text { years }\end{array}$ \\
\cline { 1 - 2 } master of sports & 4 & & & & \\
\cline { 1 - 2 } first class athletes & 3 & \multirow{2}{*}{$18.57 \pm 2.56$} & $68.00 \pm 6.45$ & $181.00 \pm 5.16$ & $6.35 \pm 2.92$ \\
\cline { 1 - 2 } $\begin{array}{c}\text { Second class } \\
\text { athletes }\end{array}$ & 7 & & & & \\
\hline
\end{tabular}

\section{Experimental subjects}

50 undergraduate students (Beijing sports university 06 level human science, female, aged 19,2), almost 1 years have not done special strength training, all subjects healthy body, during the test did not take special drugs and nutritional supplements, are voluntary to participate in this test, before the formal test were told the test process in detail. Centrifuge exercise scheme: All subjects were seated on a German ISOMED2000 isokinetic trainer, shoulder flexed forward 45 degrees, elbow and lower upper arm were placed on pads, and elbow motion range was about 150 degrees to 50 degrees. Before centrifugal training, the equilength peak torque (MIT) test of the maximum active force at 90 degrees of the elbow joint was completed, with continuous contraction for 3 seconds for each time, and the average value of the test was taken for 3 times at 30 seconds intervals. ${ }^{9}$

\section{RESULTS}

All the 14 subjects completed the training and monitoring in $\mathrm{HV}$ (high intensity) mode and high volume $(\mathrm{HI})$ mode according to the predetermined experimental scheme. As can be seen from Table 2, the average intensity of the subjects in the speed endurance training in the high volume mode was significantly higher than that in the speed endurance training in the $\mathrm{HV}$ mode $(P<0.05)$.

In HV mode, the CK value of subjects before training was $298 \pm$ $172 \mathrm{IU} / \mathrm{L}$, and reached the peak value (374 $\pm 183 \mathrm{IU} / \mathrm{L}) 24 \mathrm{~h}$ after training, significantly higher than the level before training $(P<0.05)$. CK values of the subjects returned to the pre-training level $(317 \pm 141 \mathrm{IU} / \mathrm{L}, \mathrm{P}>0.05)$. In the HI(high dose) mode, the CK value of subjects before training was $304 \pm 111 \mathrm{IU} / \mathrm{L}$, and reached the peak value $(432 \pm 186 \mathrm{IU} / \mathrm{L})$ at $24 \mathrm{~h}$ after training, significantly higher than that before training $(P<0.05)$. CK of the subjects began to recover $(363 \pm 161 \mathrm{IU} / \mathrm{L}, \mathrm{P}<0.05)$ and recovered to the pre-training level $(318 \pm 133 \mathrm{IU} / \mathrm{L}, \mathrm{P}>0.05) 72 \mathrm{~h}$ after training. In addition, $\mathrm{CK}$ values of $\mathrm{HI}$ subjects were significantly higher than those of HV subjects at 24h, 48h and $72 \mathrm{~h}$ after training (Figure 1, $\mathrm{P}<0.05$ ). ${ }^{10}$

In the HV mode, the MS value of subjects before training was $325.36 \pm$ $19.16 \mathrm{~N} / \mathrm{m}$, and at $24 \mathrm{~h}, 48 \mathrm{~h}$ and $72 \mathrm{~h}$ after training, the MS value of subjects was slightly increased, but there was no significant difference from the pre-training level ( $P>0.05)$. In $\mathrm{HI}$ mode, the MS value of subjects before training was $321.71 \pm 18.26 \mathrm{~N} / \mathrm{m}$, and $24 \mathrm{~h}$ after training, the MS value of the subjects reached the peak value $(341.43 \pm 22.91 \mathrm{~N} / \mathrm{m})$,

Table 2. Average intensity completed by subjects in HV and $\mathrm{HI}$ mode speed endurance training.

\begin{tabular}{c|c|c}
\hline & HV mode & HI mode \\
\hline Mark $(s)$ & $29.64 \pm 0.36$ & $23.87 \pm 0.36 \#$ \\
\hline intensity & $74.86 \pm 1.62$ & $92.96 \pm 1.62 \#$ \\
\hline
\end{tabular}

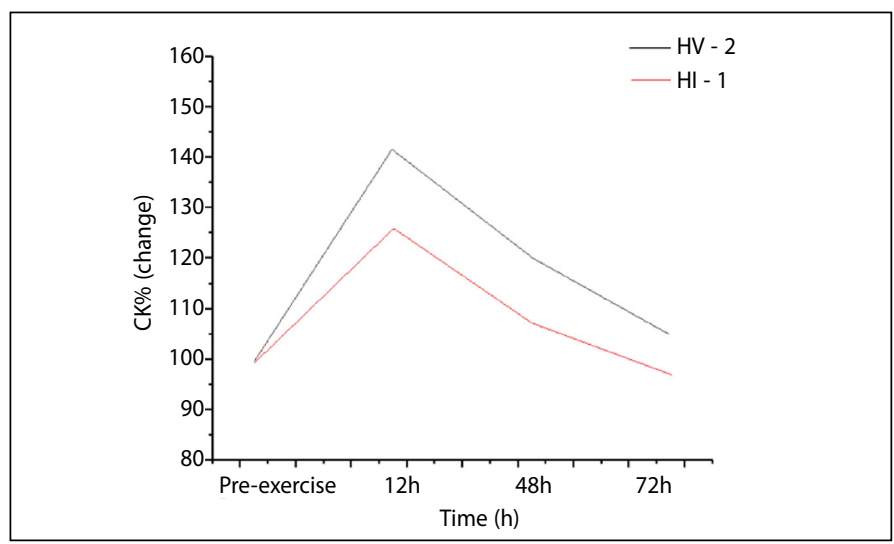

Figure 1. Changes of serum creatine kinase in subjects before and after HV and Hl training. 
which was significantly higher than that before training $(P<0.05)$. At 48 $\mathrm{h}$ after training, the MS value of the subjects began to decline $(332.71 \pm$ $20.76 \mathrm{~N} / \mathrm{m}$ ), at $72 \mathrm{~h}$ after training, it recovered to the level before training (322.00 $\pm 18.86 \mathrm{~N} / \mathrm{m}, \mathrm{P}$ BBB 0 0.05). In addition, MS values of HI subjects were significantly higher than those of $\mathrm{HV}$ subjects at 24 and $48 \mathrm{~h}$ after training (Figure 1,P<0.05), but there was no significant difference in MS values between the two subjects at $72 \mathrm{~h}$ after training.

After two training sessions, MIT decreased significantly in each group ( $P<0.05$ ), and the decrease of MIT immediately caused by the first training was 31$\}-41$, with no significant difference between groups. However, the decrease in MIT caused by repeated training was between $11 \%$ and $30 \%$, which was significantly smaller than that caused by the initial exercise. There was significant difference in the percentage decrease of MIT between the 2,8,16 and 32 day interval groups $(P<0.05)$, while there was no significant difference in the 4 day interval group $(P=0.253$ BBB 0. 05). Among them, the group with an interval of 4 days showed the most significant decrease after repeated exercise, while the percentage of decrease in the other groups showed no significant difference between groups, however, it was still observed that the 8-day interval group had the least decrease after repeated exercise, and the decrease rate after 16 days and 32 days repeated exercise was similar. (Table 3 )

Table 3. Change of MIT before and after exercise (unit Nm. Decline percentage is the ratio of difference before and after training to value before training).

\begin{tabular}{c|c|c|c|c}
\hline Block sort & \multicolumn{2}{|c|}{ Initial training session } & \multicolumn{2}{c}{ Repetitive training } \\
\hline & Top 1 & Back-1 & Top 2 & Back-2 \\
\hline Space ed 2 days & $25.78 \pm$ & $16.27 \pm$ & $20.00 \pm$ & $15.32 \pm$ \\
\hline & 8.56 & $6.60 \#$ & 8.16 & $6.26 \#$ \\
\hline Space ed 6 days & $21.86 \pm$ & 12.53 & $16.23 \pm$ & $11.75 \pm$ \\
\hline & 4.56 & $3.56 \#$ & 1.23 & $4.23 \#$ \\
\hline Space ed 8 days & $22.86 \pm$ & 15.20 & $20.45 \pm$ & $18.18 \pm$ \\
\hline & 3.51 & $2.84 \#$ & 3.21 & $3.34 \#$ \\
\hline Space ed 10 days & $26.23 \pm$ & 15.23 & $24.89 \pm$ & $20.25 \pm$ \\
\hline & 6.23 & $5.23 \#$ & 7.56 & $5.62 \#$ \\
\hline
\end{tabular}

\section{DISCUSSION}

The recovery of MIT after exercise was observed. After the initial exercise and before and after repeated exercise, MIT was expressed as the percentage before the initial exercise. In each group, the percentage of MIT before repeated exercise was observed continuously, which was essentially continuous recovery from a single exercise from 2 to 32 days: Among them, the MIT in the 2-day interval group and the 4-day interval group had not recovered completely before the repeated exercise, which was significantly different from that before the initial exercise $(P<0.05)$. The MIT in the 8-day interval group, the 16-day interval group and the 32-day interval group basically recovered to the level before the initial exercise before the repeated exercise, and it could be found that their recovery increased continuously.

\section{CONCLUSION}

In this study, the $200 \mathrm{~m}$ running event was taken as an example to explore the influence of $\mathrm{HV}$ and $\mathrm{HI}$ speed endurance training modes on muscle ultrastructure injury, the results showed that both HV and $\mathrm{HI}$ speed endurance training modes could damage the muscles of subjects to a certain extent, but the degree of injury caused by HI mode to the muscles of subjects was more serious than that of HV mode, after $\mathrm{HI}$ mode training, the time for the subjects to fully recover from micro muscle injury was longer than $48 \mathrm{~h}$. Even in the late stage of the special preparation period or the direct preparation period before the competition, coaches have to develop athletes'special endurance through $\mathrm{HI}$ mode speed endurance training mode, in the training plan should not be arranged for two consecutive days of high-intensity training content, but should be in the $\mathrm{HI}$ mode speed endurance training before or after the training of a day to arrange some low - and medium-intensity recovery exercises.

All authors declare no potential conflict of interest related to this article

AUTHORS' CONTRIBUTIONS: Each author made significant individual contributions to this manuscript. Yongfen Yang: writing and performing surgeries; Zhenting Chen: data analysis and performing surgeries, article review and intellectual concept of the article.

\section{REFERENCES}

1. Kak HB, Park SJ, Park BJ. The effect of hip abductor exercise on muscle strength and trunk stability after an injury of the lower extremities. J Phys Ther Sci. 2016;28(3):932-5. doi: 10.1589/jpts.28.932.

2. Facio FN Jr, Facio MF, Spessoto LF, Pessutti D, Reis LO, Campos SG, et al. Anti-inflammatory and anti-fibrotic effects of annexin1 on erectile function after cavernous nerve injury in rats. Int J Impot Res. 2016;28(6):221-7. doi: 10.1038/ijir.2016.32

3. An L, Li B, Ming D, Wang W. Multislice Spiral CT Image Analysis and Meta-Analysis of Inspiratory Muscle Training on Respiratory Muscle Function. J Healthc Eng. 2021;2021:1738205. doi: 10.1155/2021/1738205.

4. Huang C, Chen M, Zhang Y, Li S, Zhou P. Model-Based Analysis of Muscle Strength and EMG-Force Relation with respect to Different Patterns of Motor Unit Loss. Neural Plast. 2021;2021:5513224. doi: $10.1155 / 2021 / 5513224$.

5. Kawanishi N, Mizokami T, Niihara H, Yada K, Suzuki K. Neutrophil Depletion Attenuates Muscle Injury after Exhaustive Exercise. Med Sci Sports Exerc. 2016;48(10):1917-24. doi: 10.1249/MSS.00000000000000980.
6. Markworth JF, Maddipati KR, Cameron-Smith D. Emerging roles of pro-resolving lipid mediators in immunological and adaptive responses to exercise-induced muscle injury. Exerc Immunol Rev. 2016;22:110-34. PMID: 26853678

7. Burma JS, Copeland PV, Macaulay A, Smirl JD. The impact of high- and moderate-intensity exercise on near-point of convergence metrics. Brain Inj. 2021;35(2):248-54. doi: 10.1080/02699052.2021.1871953.

8. Zhu J, Chen Z, Fang Y, Duan W, Xie Y, Ma C. Injury of muscular but not cutaneous nerve drives acute neuropathic pain in rats. Neurosci Bull. 2020;36(5):453-62. doi: 10.1007/s12264-019-00462-w.

9. Shen $M$, Yin $H$, Miao Z. Control effect of functional strength training for aerobics sports injury. J Pak Med Assoc. 2020;70 [Special Issue](9):94-7. PMID: 33177735.

10. de la Motte SJ, Lisman P, Sabatino M, Beutler Al, O'Connor FG, Deuster PA. The Relationship Between Functional Movement, Balance Deficits, and Previous Injury History in Deploying Marine Warfighters. J Strength Cond Res. 2016;30(6):1619-25. doi: 10.1519/JSC.0000000000000850. 